\title{
ANALISIS PENINGKATAN PENJUALAN PRODUK PH METER DENGAN METODA QUALITY FUNCTION DEPLOYMENT(QFD) (Studi kasus pada PT. PRATAMA GRAHA SEMESTA (PGS)
}

\author{
Niera Feblidiyanti ${ }^{*}$ \\ email:nira_coeet@yahoo.com
}

\begin{abstract}
ABSTRAK
PT. Pratama Graha Semesta (PGS) adalah perusahaan yang mewakili beberapa perusahaan manufaktur internasional, dari itu semua kami menyediakan banyak produk. Oleh karena itu perusahaan harus memperhatikan beberapa faktor di antaranya barang, perantara dan pemasaran. Untuk menghasilkan jasa dan produk yang sesuai dengan kebutuhan konsumen maka perusahaan harus mengidentifikasi terlebih dahulu salah satunya dengan metoda Quality Function Deployment (QFD). QFD merupakan metoda yang mampu mengintegrasikan dan mengevaluasi keinginan konsumen melalui pengembangan dan perancangan produk atau jasa.

Jenis produk $\mathrm{pH}$ meter yang banyak digunakan oleh konsumen adalah $\mathrm{pH}$ meter merk Mettler dengan jumlah persentase 57,14\%. Terdapat 14 atribut yang berpengaruh terhadap kepuasan konsumen yaitu kemampuan menganalisa sampel, kestabilan hasil, warna monitor, berat produk, dimensi produk, bentuk produk, keamanan bahan pembuat, bentuk kemasan, dimensi kemasan, desain kemasan, ada logo, ada informasi standar aksesories, ada ijin Deperindag dan harga jual.
\end{abstract}

Kata Kunci $=$ Penjualan, pH meter, Quality Function Deployment (QFD

\begin{abstract}
PT. Pratama Graha Semesta (PGS) is a company that represents several international manufacturing companies, from which we provide many products. There fore companies must pay attention to several factors including goods, intermediaries and marketing. To produce services and products that are in accordance with consumer needs, the company must first identify one of them by the Quality Function Deployment (QFD) method. QFD is a method that is able to integrate and evaluate consumer desires through the development and design of products or services

Type $\mathrm{pH}$ meter products are widely used by consumers are brand Mettler $\mathrm{pH}$ meter with a percentage of $57.14 \%$. There are 14 attributes that influence customer satisfaction is the ability to analyze the sample, the stability of the results, color monitors, product weight, product dimensions, product shape, fabric security, forms of packaging, packaging dimensions, packaging design, no logo, no information standard accessories, there Ministry permission and selling prices.
\end{abstract}

Keyword = Sales, pH meter, Quality Function Deployment (QFD) 
A. Pendahuluan.

Dunia bisnis dewasa ini perkembangannya sangat pesat, peluang untuk berbisnis sangat luas dan semakin besar, tapi di antara hal tersebut persaingan susah diprediksi dan makin ketat. Maka dari itu perusahaan harus dapat menciptakan dan menghasilan bisnis yang memiliki keunggulan kompetitif agar bisa bersaing dikancah industry, salah satu di antaranya melalui pelayanan yang berkualitas dan menyediakan produk barang atau jasa yang sesuai dengan apa yang di inginkan oleh konsumen.

PT. Pratama Graha Semesta (PGS) adalah perusahaan yang mewakili beberapa perusahaan manufaktur internasional, dari itu semua kami menyediakan banyak produk yang kami tangani dan kami handle yang terkait dengan instrument/alat untuk proses industry dan sistem kontrol dibawah kondisi ekstrem yang sering ditemui diproses industri. Bukan hanya itu kami juga menyediakan support sepenuhnya dan back up dengan manufacturing atau agen yang berwenang untuk teknik dan pemasaran komersial, serta kami harus mampu bersaing, dari perusahaan- perusahaan yang bergerak dibidang yang sejenis. Untuk memenuhi permintan konsumen yang terus meningkat di karenakan perkembangan dunia industri yang semakin pesat mengharuskan PT. PGS membuka anak cabang di sejumlah kota besar seperti Surabaya, Balikpapan dan Bontang. Bukan hanya itu melihat dari keberhasilan dari tiga cabang yang telah ada dalam memenuhi kebutuhan konsumen maka dalam waktu dekat PT. PGS akan membuka anak cabang lain, terutama diwilayah Sumatra, Sulawesi dan Irian. Ini merupakan salah satu bukti keberhasilan PT. PGS di dunia industri sekaligus membantu pemerintah dalam menciptakan lapangan pekerjaan.

PT. Pratama Graha Semesta sendiri beralamat di Komplek Lodan Center Blok. H-11, Jalan Lodan Center Raya No. 2, Ancol Pademangan, Jakarta Utara. Produk-produk yang ditawarkan oleh perusahaan ini jenisnya beragam akan tetapi usaha yang dijalankan lebih mengarah kepada bidang-bidang seperti perindustrian, kelautan, laboratorium, lingkungan dan keselamatan.

Kualitas suatu produk adalah hal yang sangat diperhatikan oleh konsumen. Untuk mencapai kualitas yang diharapkan di antaranya dilakukan melalui cara statistik dengan menggunakan metode seven tools. Statistik inferensial adalah "pengambilan keputusan tentang suatu proses berdasarkan data yang diperoleh 
dari sampel untuk menggambarkan karakteristik atau ciri dari suatu populsi. Dengan demikian dalam statistic inferensial dilakukan suatu generalisasi dan hal yang bersifat khusus (kecil) ke hal yang lebih luas (umum). Oleh karena itu, statistic inferensial disebut uga statistic induktif atau statistic penarikan kesimpulan. Pada statistic inferensial biasanya dilakukan pengujian hipotesis dan pendugaan mengenai karakteristik (ciri) dari suatu populasi, seperti mean dan uji T" (Sugiyono, 2006). Maka dari itu untuk berkomunikasi mengenai kualitas statistik juga sering digunakan.

Keberadaan sebuah perusahaan seperti PT. PGS dalam mempertahankan peranannya untuk mengembangan dan mendapatkan keuntungan telah diakui didunia pemasaran. Hal ini menyebabkan pertumbuhan persaingan antara sesama perusahaan sejenis semakin ketat sehingga perusahaan berlombalomba melempar jumlah dan jenis produk ke pasaran.

Untuk meningkatkan penjualan dan mendapatkan keuntungan lebih maka perusahaan harus bisa memperlihatkan tingkat keberhasilannya dalam persaingan yang semakin ketat. Semua itu ditunjang dengan program-program pemasaran yang baik diantaranya jalur aktivitas barang dari produsen hingga akhirnya sampai ketangan konsumen. Dengan pendistribusian yang baik tersebut maka kebutuhan dan keinginan konsumen dapat terpenuhi dengan tepat dan efesien sehingga tujuan perusahaan dapat tercapai dengan maksimal.

PT. Pratama Graha Semesta (PGS) adalah perusahaan yang mewakili beberapa perusahaan manufaktur internasional, dari itu semua kami menyediakan banyak produk. Oleh karena itu perusahaan harus memperhatikan beberapa faktor di antaranya barang, perantara dan pemasaran. Untuk mencapai target penjualan maksimal yang dilihat dari peranan pemasaran maka penulis mengambil judul “Analisis Peningkatan Penjualan Produk pH Meter Dengan Metoda Quality Function Deployment (QFD)".

Quality Function Deployment (QFD) merupakan metoda yang mampu mengintegrasikan dan mengevaluasi keinginan konsumen melalui pengembangan dan perancangan produk atau jasa. Sehingga perusahaan dapat menciptakan nilai tambah dan mepunyai keunggulan yang kopetitif melalui produk dan jasa yang diinginkan konsumen.

Jika kualitas baik maka memberikan kepuasan tersendiri kepada konsumen dan akan meningkatkan keuntungan pada sebuah perusahaan. Konsumen akan 
mencari produk yang berkualitas tinggi dan sesuai dengan selera yang diinginkan. Oleh sebab itu PT. PGS sangat memperhatikan kualitas dari produk yang dijual.

\section{B. Perumusan Masalah}

Berpangkal dari penguraian masalah yang ada di PT. Pratama Graha Semesta, maka dapat dirumuskan masalah sebagai berikut:

1. Bagaimana cara mengukur jumlah pasar kompetitor?

2. Metode apa yang dipakai dalam aspek pemasaran yang digunakan perusahaan?

3. Bagaimana cara mengetahui selera konsumen terhadap produk perusahaan?

\section{Tujuan Penelitian}

1. Untuk mengetahui jenis produk $\mathrm{pH}$ meter yang banyak digunakan konsumen.

2. Untuk mengetahui atribut kebutuhan dan kepuasan konsumen.

3. Untuk mengetahui keunggulan produk $\mathrm{pH}$ meter yang dijadikan pesaing.

\section{Landasan Teori}

Kualitas merupakan kata yang sangat sering kita dengar dalam kehidupan, baik dibahas secara umum maupun khusus oleh orang-orang disekililing kita, contohnya kualitas sebuah produk dalam dan luar negeri dimana sebagian orang akan memilih produk luar lebih bagus dari produk kita sendiri. Jadi apa sebenarya makna kualitas itu? Pertanyaan ini sangat banyak jawabannya, karena maknanya akan berlainan bagi setiap orang dan tergantung pada konteksnya. Dimana kualitas mempunyai kriteria berubah dar waktu ke waktu dilihat dari masing-masing orang, yang mana akan mempunyai penilaian yang berbeda akan kualitas. (Tjipto, F., Diana A., 1997). Pengertian kualitas yang sebenarnya akan sulit difahami, walaupun pada hakekatnya penjelasan dan rincian kualitas itu telah di paparkan. Kesesuaian dan desain baik atau tidaknya suatu produk dan jasa sering dijadikan ukuran untuk menentukan konsep sebuah kualitas. Spesifikasi produk dapat dilihat dari bentuk kualitas desainnya, namun kualitas kesesuaian merupakan berapa ukuran produk dan jasa dapat dipenuhi, 
dengan persyaratan spesifikasi dalam kondisi dinamis yang mencakup manusia, produk, jasa dan lingkungan yang sesuai atau melampuai keinginan. (Tjiptono, F., Diana A., 1997). Kepuasan pelanggan dengan perusahaan dapat terjalin dengan kuat karena adanya kualitas yang mendorong hubungan tersebut dapat terjadi (Tjipto, F., Diana A., 1997). Pengertian kualitas berdasarkan Goetsch, D.L. dan S. Davis (1994) "merupakan suatu kondisi dinamis yang berhubungan dengan produk, jasa, manusia, proses, dan lingkungan yang memenuhi atau melebihi harapan".

Kepuasan pelanggan akan kualitas tidak saja dipengaruhi oleh produk itu dapat dilihat dari perkembangan manajeman kualitas (Total Quality Management) itu sendiri. Dalam hal ini tanggung jawab terhadap kualitas tidak saja menjadi tanggung jawab suatu bagian, tetapi sudah jadi tanggung jawab semua orang di perusahaan, pola inilah disebut Total Quality Management

Menurut (Tjiptono, F., 1997). "Konsep kepuasan pelanggan dewasa ini kepedulian terhadap kepuasan ataupun ketidakpuasan pelanggan makin besar, karena banyak pihak yang memperhatikan tentang hal ini. Jadi pelanggan yang paling banyak berhubungan langsung dengan kepuasan atau ketidakpuasan pelanggan adalah distributor, konsumen, konsumeris, dan peneliti pola konsumen".

Schnaars dalam Tjiptono, F., 1997, "tujuan dari suatu bisnis untuk membuat para pelanggan merasa puas. Terciptanya kepuasan pelanggan dapat memberikan manfaat, hubungan hubungan antara perusahaan dan pelanggannya menjadi harmonis, memberikan landasan yang baik pembelian ulang dan terciptanya loyalitas pelanggan dan membuat semua topik reomendasi dari mulut ke mulut (word of mouth) yang menguntungkan bagi perusahaan".

Secara konseptual defenisi produk merupakan penjabaran produsen terhadap persepsi dan keinginan konsumen dalam produksinya, baik berupa barang, kemasan, merek, label, pelayanan dan jaminan yag dapat ditawarkan dalam mencapai tujuan organisasi yang dilihat dari kompetensi perusahaan dan pangsa pasar yag dituju.

Proses pengeluaran produk untuk memenuhi kebutuhan dan keinginan pelaggan yang dapat dipastikan merupakan tujuan prinsip Quality Function Deployment (QFD). Dalam prosesnya QFD memiliki 2 sasaran utama: 
1. Menghindari kekalahan dalam persaingan yang menyebabkan jatuhnya harga produk dipasar (marketing misses)

2. Peningkatan efesiensi dalam pengembangan produk.

Karena dua sasaran utama di atas QFD selalu dikaitkan dengan Voice of Customer (VOC) atau customer focused design dimana QFD selalu berfokus pada pelanggan dan mendengarkan suara pelanggan. Selain itu QFD bertujuan meringankan kerja para engineer dan mempersingkat waktu yang digunakan untuk menciptakan produk. Dalam aktifitasnya QFD yang mengartikan kebutuhan dan keingginan pelanggan dalam tiap tahapanya, dimana aktifitas penelitian yang dimaksud berupa:

1. market research

2. basic research

3. invention

4. prototype testing

5. final-product or service testing

6. after-sales service and troubleshooting

Menurut (Oakland J.S 1993) "Kesemuanya dilakukan oleh orang yang memiliki keahlian yang berbeda berbeda dalam tim yang komposisinya tergantung pada banyak faktor, termasuk jenis produk atau jasa yang dikembangkan serta ukuran operasinya".

Strategi penjualan dalam pemasaran untuk menarik serta meningkatkan minat pelanggan sehingga penjualan produk kian tinggi ada beberapa jenis, diantaranya dalam mencapai pemakaian industri ada 4 jenis saluran distribusi yang sering digunakan:

a. Produsen-Pemakai Industri

b. Produsen-Distribusi Industri-Pemakai Industri

c. Produsen-Agen-Pemakai Industri

d. Produsen-Agen-Distributor Industri-Pemakai Industri.

Sampai saat ini, untuk menarik minat konsumen banyak orang atau perusahaan yang mengalami kesulitan. Jadi jika dilihat dari bisnis/usaha yang dijalankan maka dapat dipastikan tidak berjalan dengan semestinya, karena hasil yang di dapat kalah tinggi dengan biaya operasional yang dikeluarkan dalam arti 
kata penjualan masih dibawah rata-rata dari target perusahaan. Lalu, strategi apa yang baiknya dilakukan agar konsumen tertarik akan produk yang dijual? adapun tips strategi pemasaran berikut ini dapat di praktekan:

1. Berikan informasi produk ke konsumen serta keuntungan yang akan mereka dapatkan jika membeli produk kita.

2. Publikasikan program-program promosi yang anda lakukan. Penawaran promosi seperti discount (potongan harga)

3. Bagikan contoh produk gratis kepada konsumen. Dari sampel gratis yang diberikan, konsumen akan mengenal dan mengetaui produk yang di tawarkan.

4. Buatlah program khusus untuk membangun loyalitas konsumen. Bagi para pelaku usaha konsumen adalah aset karna untuk menjaga kestabilan penjualan, semakin loyal konsumen semakin bagus nilai pendapatan perusahaan.

5. Tunjukan kelebihan dan inovasi produk yang tidak dimiliki oleh pesaing. Karena konsumen akan lebih tertarik jika produk yang kita tawarkan beda dengan produk lain.

\section{E. Metodologi}

Obyek dalam penelitian ini adalah PT. Pratama Graha Semesta yang beralamat di di Komplek Lodan Center Blok. H-11, Jalan Lodan Center Raya No. 2, Ancol Pademangan, Jakarta Utara. Subyek penelitiannya adalah produk $\mathrm{pH}$ meter yang dijual di PT. Pratama Graha Semesta. Penelitian ini dilakukan untuk mengetahui bagaimana kualitas produk yang dijual agar meningkatkan penjulan di PT. Pratama Graha Semesta.

Jenis Penelitian ini adalah deskriptif kualitatif Langkah-langkah dalam pengolahan dan analisa data produk berfokus kebutuhan pelanggan ini diawali dengan penentuan atribut kebutuhan konsumen dan survei pendahuluan sebagai input untuk melakukan survei pelanggan. Hasil survei pelanggan akan berfungsi sebagai input dalam proses pengembangan produk. Proses pengembangan produk dengan tahapan pembuatan House of Quality (HoQ), pembuatan alternatif konsep pengembangan produk, pemilihan konsep, pembuatan gabungan part deployment dan tahap terakhir adalah pengujian hasil pengembangan produk ke pelanggan. 
Metode pengumpulan data primer dengan :

1. Pengamatan.

2. Wawancara dan diskusi

3. Kuesioner

4. Gambaran umum perusahaan stuktur organisasi dan data lainnya

\section{F. Hasil dan Pembahasan}

\section{Hasil}

Obyek dalam penelitian ini adalah PT. Pratama Graha Semesta yang beralamat di di Komplek Lodan Center Blok. H-11, Jalan Lodan Center Raya No. 2, Ancol Pademangan, Jakarta Utara. Subyek penelitiannya adalah produk pH meter yang dijual di PT. Pratama Graha Semesta dengan data yang di dapat sebagai berikut:

1) Data Merk pH Meter yang digunakan.

Tabel Merk pH Meter yang Paling Sering Digunakan

\begin{tabular}{|l|c|c|c|}
\hline Merk pH Meter & $\begin{array}{c}\text { Jumlah Responden } \\
\text { yang menggunakan }\end{array}$ & Persentase & $\begin{array}{c}\text { Persentase } \\
\text { Kumulatif }\end{array}$ \\
\hline Metler & 40 & $57,14 \%$ & $57,14 \%$ \\
\hline Hanna & 8 & $11,43 \%$ & $82,86 \%$ \\
\hline Toa dkk & 10 & $14,29 \%$ & $71,43 \%$ \\
\hline Hach & 8 & $11,43 \%$ & $94,29 \%$ \\
\hline Togawa & 2 & $2,86 \%$ & $97,14 \%$ \\
\hline Chuo & 1 & $1,43 \%$ & $98,57 \%$ \\
\hline Lakmus & 1 & $1,43 \%$ & $100 \%$ \\
\hline JUMLAH & 70 & $100 \%$ & \\
\hline
\end{tabular}

Berdasar hasil analisa dengan diagram Pareto yang terdapat pada Lampiran 1 maka merk Metler, Hanna dan Toa dkk merupakan merk yang akan dijadikan sebagai produk kompetitor.

\section{2) Atribut Kebutuhan Konsumen}

Tabel Daftar Atribut Kebutuhan Konsumen 


\begin{tabular}{|l|l|l|}
\hline \multicolumn{1}{|c|}{ Primer } & \multicolumn{1}{|c|}{ Sekunder } & \multicolumn{1}{c|}{ Tersier } \\
\hline Kualitas Produk & Karakteristik & Kemampuan menganalisa sampel \\
\hline & & Kestabilan hasil \\
\hline & & Warna monitor \\
\hline & & Berat \\
\hline & & Dimensi \\
\hline & & Bentuk \\
\hline Kemasan Produk & Penampilan & Keamanan bahan \\
\hline & & Bentuk kemasan \\
\hline & & Dimensi kemasan \\
\hline & & Desain kemasan \\
\hline & & Terdapat logo merk \\
\hline & & Terdapat informasi standar aksesories \\
\hline Harga & & Terdapat ijin Deperindag \\
\hline
\end{tabular}

3) Keunggulan Produk pH Meter Pesaing

Tabel Keunggulan Produk pH Meter Pesaing

\begin{tabular}{|l|l|}
\hline \multicolumn{1}{|c|}{ Merk pH Meter } & \multicolumn{1}{|c|}{ Keunggulan yang Dimiliki } \\
\hline Mettler & Hasil pembacaan stabil \\
\hline & Terdapat standar accessories \\
\hline & Lebih sensitif \\
\hline Hanna & Harga lebih murah \\
\hline & Terdapat type portable \\
\hline Toa $d k k$ & Harga lebih murah \\
\hline & Sensitif \\
\hline
\end{tabular}

\section{Pengolahan Data}

Nilai kepentingan menunjukkan kontribusi peran dari masing-masing atribut terhadap kepuasan konsumen. Dari data hasil survei, diperoleh bahwa tingkat kepentingan tertinggi adalah kemampuan Menganalisa sampel dan terendah adalah warna monitor $\mathrm{pH}$ meter. 
Hasil perhitungan mean pada kuesioner 1 menunjukkan bahwa dari empat belas atribut ada tujuh atribut yang penting (nilai mean lebih besar atau sama dengan 3). Atribut yang penting adalah kemampuan menganalisa data, kestabilan hasil, keamanan bahan, terdapat logo merk, terdapat informasi aksesories standar, terdapat ijin Deperindag dan tingkat harga.

Nilai kepuasan konsumen terhadap produk saat ini ditetapkan sebagai performansi awal. Sedangkan hasil dari kuesioner ketiga menunjukkan nilai kepuasan yang diharapkan yang akan menjadi nilai goal masing-masing atribut.

Hasil perhitungan mean pada kuesioner 2, bisa digambarkan dalam grafik radar seperti ditampilkan pada Lampiran. Dari grafik radar tersebut dapat dilihat bahwa masih terdapat gap antara tingkat kepuasan Horiba dengan produk kompetitor. Dibanding dengan produk Metler, Horiba unggul hanya pada atribut model, dan harga saja. Dibandingkan dengan Hanna, Horiba unggul di enam atribut yaitu kemampuan menganalisa sampel, berat, keamanan komposisi, kestabilan hasil, adanya izin Deperindag, dan terdapat standar aksesories. Sedangkan jika dibandingkan dengan tingkat kepuasan produk Toa dkk, Horiba hanya unggul pada atribut kemampuan menganalisa sampel, dan kestabilan hasil. Apabila dibandingkan dengan tingkat kepuasan yang diharapkan (target) maka hanya atribut terdapat kestabilan saja yang nilainya lebih besar. Hal ini menunjukkan bahwa masih harus dilakukan pengembangan produk.

\section{Pengumpulan Data Keluhan Konsumen}

Selain informasi yang didapatkan dari pengisian kuesioner, survei konsumen juga memperjelas kebutuhan konsumen terhadap atribut produk dengan mengumpulkan informasi keluhan konsumen. Pengumpulan informasi tambahan dilakukan dengan wawancara dengan tidak terstruktur. Hasil dari wawancara tersebut kemudian diringkas dalam Tabel:

Tabel Hasil Perhitungan Mean Kuesioner 1, 2 dan 3

\begin{tabular}{|c|c|c|c|c|c|c|c|}
\hline No & Atribut & Kuesioner 1 & \multicolumn{4}{|c|}{ Kuesioner 2 } & $\begin{array}{c}\text { Kuesioner } \\
3\end{array}$ \\
\cline { 3 - 7 } & & $\begin{array}{c}\text { Tingkat } \\
\text { Kepentingan }\end{array}$ & $\mathbf{X}$ & Metler & Hanna & $\begin{array}{c}\text { Toa } \\
\text { dkk }\end{array}$ & Target \\
\hline 1 & Kemampuan & 3,90 & 3,16 & 3,24 & 3,14 & 3,43 & 3,61 \\
\hline
\end{tabular}




\begin{tabular}{|c|c|c|c|c|c|c|c|}
\hline & $\begin{array}{l}\text { menganalisa } \\
\text { hasil }\end{array}$ & & & & & & \\
\hline 2 & $\begin{array}{l}\text { Kestabilan } \\
\text { hasil }\end{array}$ & 3,29 & 2,27 & 3,01 & 2,64 & 3,10 & 3,24 \\
\hline 3 & Warna Monitor & 2,40 & 2,46 & 2,94 & 2,86 & 3,23 & 2,97 \\
\hline 4 & Berat total & 2,43 & 2,96 & 2,90 & 2,90 & 3,14 & 2,97 \\
\hline 5 & Ukuran & 2,60 & 2,74 & 2,83 & 2,80 & 2,87 & 3,03 \\
\hline 6 & Bentuk & 2,49 & 2,24 & 2,91 & 2,76 & 2,87 & 3,13 \\
\hline 7 & $\begin{array}{l}\text { Keamanan } \\
\text { bahan }\end{array}$ & 3,77 & 2,87 & 3,01 & 2,76 & 2,99 & 3,40 \\
\hline 8 & $\begin{array}{l}\text { Desain } \\
\text { kemasan } \\
\text { menarik }\end{array}$ & 2,90 & 2,53 & 2,89 & 2,69 & 2,99 & 2,93 \\
\hline 9 & $\begin{array}{l}\text { Bentuk } \\
\text { kemasan }\end{array}$ & 2,73 & 2,67 & 2,93 & 2,90 & 2,90 & 2,97 \\
\hline 10 & $\begin{array}{l}\text { Ukuran } \\
\text { kemasan }\end{array}$ & 2,59 & 2,89 & 2,97 & 2,86 & 2,90 & 2,96 \\
\hline 11 & $\begin{array}{l}\text { Terdapat logo } \\
\text { merk }\end{array}$ & 3,20 & 2,96 & 3,17 & 2,96 & 3,23 & 3,13 \\
\hline 12 & $\begin{array}{l}\text { Terdapat } \\
\text { informasi } \\
\text { standar } \\
\text { aksesories }\end{array}$ & 3,53 & 2,67 & 3,17 & 3,09 & 3,27 & 3,23 \\
\hline 13 & $\begin{array}{l}\text { Terdapat izin } \\
\text { Deperindag }\end{array}$ & 3,76 & 3,31 & 3,27 & 3,27 & 3,31 & 3,43 \\
\hline 14 & Tingkat harga & 3,20 & 2,71 & 2,89 & 3,29 & 2,76 & 3,33 \\
\hline
\end{tabular}

Tabel Keluhan Konsumen

\begin{tabular}{|l|l|}
\hline \multicolumn{1}{|c|}{ ATRIBUT } & \multicolumn{1}{c|}{ KETERANGAN TAMBAHAN } \\
\hline Dimensi & Terlalu tebal, tidak nyaman di genggaman \\
\hline Desain kemasan & $\begin{array}{l}\text { Desain kemasan kurang menarik } \\
\text { Instruksi kerja di dalam bahasa inggris }\end{array}$ \\
\hline Terdapat logo merk & Berkaitan dengan nilai estetika \\
\hline Terdapat informasi standar & Belum ada informasi standar aksesories \\
\hline
\end{tabular}




\begin{tabular}{|l|l|}
\hline aksesories & \\
\hline Harga jual & Harga jual di pasaran terlalu Tinggi \\
\hline
\end{tabular}

\section{Memasukkan Data Kebutuhan Konsumen}

Atribut kebutuhan konsumen dimasukkan pada bagian kolom customer requirements. Berdasar hasil langkah penelitian sebelumnya ditetapkan ada empat belas atribut produk yang berpengaruh pada kepuasan konsumen.

\section{Memasukkan Nilai Hasil Survei}

Nilai kepentingan produk $\mathrm{pH}$ meter dan nilai kepuasan produk Horiba dan kompetitorserta tingkat kepuasan yang diharapkan dari hasil survei konsumen dimasukkan pada kolom planning matrix.

\section{Penentuan Technical Relations}

Penentuan technical relations dilakukan dengan wawancara dengan bagian produksi perusahaan dan studi literatur. tabel menampilkan hasil penentuan technical relations.

\section{Mengisi Kolom Correlation Matrix}

Kolom correlation matrix menunjukkan hubungan antar technical requirements, apakah saling mendukung atau ada konflik. Penentuan hubungan ini ditentukan juga dengan wawancara dengan bagian principle.

Tabel Daftar Technical Relations

\begin{tabular}{|c|l|l|}
\hline No & \multicolumn{1}{|c|}{ Atribut Produk } & \multicolumn{1}{c|}{ Technical Relations } \\
\hline 1 & $\begin{array}{l}\text { Kemampuan meganalisa } \\
\text { sampel }\end{array}$ & Jenis Electrode \\
\cline { 3 - 3 } & & Jenis sampel \\
\cline { 3 - 3 } & & Jenis Buffer \\
\hline 2 & Data & Jumlah yang bisa di simpan \\
\hline
\end{tabular}




\begin{tabular}{|c|c|c|}
\hline 3 & Berat & Bentuk cetakan \\
\hline 4 & Dimensi & Bentuk cetakan \\
\hline 5 & Bentuk & Bentuk cetakan \\
\hline \multirow[t]{2}{*}{6} & \multirow[t]{2}{*}{ Bentuk kemasan } & Bahan kemasan \\
\hline & & Bentuk cetakan \\
\hline \multirow[t]{2}{*}{7} & \multirow[t]{2}{*}{ Dimensi kemasan } & Bahan kemasan \\
\hline & & Bentuk cetakan \\
\hline \multirow[t]{2}{*}{8} & \multirow[t]{2}{*}{ Desain Kemasan } & Bahan kemasan \\
\hline & & Bentuk cetakan \\
\hline \multicolumn{3}{|c|}{ Tabel Daftar Technical Relations (Lanjutan) } \\
\hline 9 & Terdapat logo merk & Aturan Deperindag untuk label \\
\hline 10 & $\begin{array}{l}\text { Terdapat informasi standar } \\
\text { aksesories }\end{array}$ & Aturan Deperindag untuk label \\
\hline 11 & Terdapat izin Deperindag & Aturan Deperindag \\
\hline \multirow[t]{6}{*}{12} & \multirow[t]{6}{*}{ Harga jual } & Jenis Electode \\
\hline & & Jenis Buffer \\
\hline & & Jenis type \\
\hline & & Jenis channel \\
\hline & & Biaya kirim (pajak) \\
\hline & & Biaya manufacturing overhead \\
\hline
\end{tabular}

\section{Pembuatan Alternatif Konsep Pengembangan Produk}

\section{1) Perumusan Atribut Yang Harus Dikembangkan}

Sebelum pembuatan alternatif konsep, perlu dirumuskan konsep pengembangan yang akan dilakukan. Konsep pengembangan berisi hasil analisis terhadap atribut yang harus dikembangkan. Oleh karena itu, atribut yang dikembangkan diprioritaskan yang penting, mean pada kuesioner pertama lebih besar atau sama dengan 3, dan pada atribut produk yang belum puas saat ini, mean pada kuesioner 2 bagian Horiba kurang dari 3. Pada tabel menampilkan atribut produk yang memenuhi kriteria tersebut sekaligus menampilkan persentase dan persentase kumulatif.

Tabel Daftar Prioritas Atribut Yang Dikembangkan

\begin{tabular}{|l|l|l|l|}
\hline Peringkat & Atribut & Persentase & Persentase \\
\hline
\end{tabular}




\begin{tabular}{|c|l|c|c|}
\hline & & & Kumulatif \\
\hline 1 & Kemampuan menganalisa sampel & $17.83 \%$ & $17.83 \%$ \\
\hline 2 & Kestabilan hasil & $17.49 \%$ & $35.32 \%$ \\
\hline 3 & $\begin{array}{l}\text { Terdapat informasi standar } \\
\text { aksesories }\end{array}$ & $16.81 \%$ & $52.12 \%$ \\
\hline 4 & Keamanan bahan & $14.81 \%$ & $66.94 \%$ \\
\hline 5 & Tingkat harga & $12.38 \%$ & $79.31 \%$ \\
\hline 7 & Terdapat logo merk & $10.57 \%$ & $89.88 \%$ \\
\hline
\end{tabular}

Tujuh atribut dalam table dirasa masih terlalu banyak dalam proses pengembangan produk tahap awal ini. Oleh karena itu dilakukan analisis lebih lanjut untuk mendapatkan rencana pengembangan yang lebih mendesak. Analisis dilakukan dengan menggunakan Diagram Pareto. Atribut yang mendekati persentase kumulatif $80 \%$ yang akan dikembangkan. Tabel merupakan daftar atribut yang akan dikembangkan.

Tabel Daftar Atribut Yang Dikembangkan

\begin{tabular}{|c|l|l|}
\hline Peringkat & \multicolumn{1}{|c|}{ Atribut } & \multicolumn{1}{|c|}{$\begin{array}{c}\text { Klasifikasi } \\
\text { Atribut } \\
\text { Primer }\end{array}$} \\
\hline 1 & Kemampuan analisa sampel & Produk \\
\hline 2 & Keamanan bahan & Produk \\
\hline 3 & Terdapat informasi standar aksesories & Kemasan \\
\hline 4 & Tingkat harga & Harga \\
\hline
\end{tabular}

2) Pembuatan Konsep Pengembangan Produk

Tabel Arahan Solusi Pengembangan

\begin{tabular}{|l|l|l|}
\hline Atribut primer & \multicolumn{1}{|c|}{ Keluhan } & \multicolumn{1}{c|}{ Arahan Solusi } \\
\hline Dimensi & $\begin{array}{l}\text { Terlalu tebal sehingga sulit } \\
\text { dipegang }\end{array}$ & $\begin{array}{l}\text { Memperkecil } \\
\text { dimensi }\end{array}$ \\
\hline
\end{tabular}




\begin{tabular}{|l|l|l|}
\hline Terdapat Logo & $\begin{array}{l}\text { Berkaitan dengan nilai } \\
\text { estetika }\end{array}$ & $\begin{array}{l}\text { Aturan Deperindag untuk } \\
\text { label dipenuhi }\end{array}$ \\
\hline $\begin{array}{l}\text { Terdapat } \\
\text { informasi } \\
\text { standar } \\
\text { aksesories }\end{array}$ & $\begin{array}{l}\text { Tidak ada informasi standar } \\
\text { aksesories pada kemasan }\end{array}$ & $\begin{array}{l}\text { Informasi secara lisan dan } \\
\text { menggunakan buku } \\
\text { petunjuk. }\end{array}$ \\
\hline $\begin{array}{l}\text { Desain } \\
\text { kemasan }\end{array}$ & $\begin{array}{l}\text { Desain kemasan kurang } \\
\text { menarik } \\
\text { Instruksi kerja di dalam } \\
\text { bahasa inggris }\end{array}$ & $\begin{array}{l}\text { Kemasan dibuat dalam 2 } \\
\text { bahasa,bahasa Inggris dan } \\
\text { Indonesia }\end{array}$ \\
\hline Tingkat harga & Harga jual tinggi & $\begin{array}{l}\text { Efisiensi terhadap faktor- } \\
\text { faktor pembiayaan (pajak, } \\
\text { biaya kemasan, biaya } \\
\text { overhead, biaya } \\
\text { pemasaran) }\end{array}$ \\
\hline
\end{tabular}

Pada penelitian ini tidak akan dibahas efisiensi faktor-faktor biaya secara detail. Masalah harga dibatasi dengan pembatasan penambahan biaya maksimal yang mengakibatkan kenaikan harga jual produk ke pasaran dengan kanaikan yang tidak terlalu tinggi dalam melakukan pengembangan produk. Biaya akan dijadikan batasan pada pemilihan alternatif konsep pengembangan yang akan dilakukan.

\section{3) Distribusi Awal}

Setelah ditetapkan strategi untuk pengembangan produk maka langkah selanjutnya adalah melakukan distribusi awal produk hasil proses analisis pengembangan produk. Hasil distribusi awal pengembangan produk kemudian di uji coba ditawarkan kepada customer.

\section{4) Pengujian Produk Pengembangan}

Pengujian ini bertujuan untuk mengetahui tingkat kepuasan konsumen terhadap produk hasil pengembangan. Produk hasil pengembangan dikatakan sukses jika dapat meningkatkan kepuasan konsumen. 


\section{5) Pembuatan Kuesioner}

Kuesioner pengujian yang dibagikan kepada responden. Kuesioner ini bertujuan mengetahui tingkat kepuasan atribut produk yang dikembangkan yaitu kestabialan hasil dan keakuratan hasil.

\section{6) Penyebaran Kuesioner}

Kuesioner yang telah disusun kemudian disebarkan ke responden dengan teknik purposive non probablity sampling. Karakteristik responden yang dipilih sama dengan karakteristik responden pada survei konsumen. Sebelum mengisi kuesioner responden diminta menggunakan produk hasil pengembangan.

Berdasar hasil analisis terhadap pada HoQ maka diputuskan bahwa atribut yang akan dikembangkan adalah kualitas produk seperti keakuratan pembacaan, kestabilan hasil dan harga produk. Selanjutnya dibuat alternatif pengembangan produk dan dilakukan pemilihan alternatif yang terbaik.

Pengembangan produk dilakukan dengan menambah electrode, sebagai probe yang digunakan untuk menganalisa sampel, menambah alat pelindung untuk menjaga agar electrode tidak cepat rusak. Pengembangan produk dilakukan dengan batasan kenaikan biaya untuk pengembangan produk tidak boleh menyebabkan kenaikan harga jual produk yang terlalu tinggi.

Hasil pengujian produk hasil pengembangan menunjukkan bahwa tingkat kepuasan terhadap atribut kualitas produk seperti keakuratan produk, kestabilan hasil mengalami peningkatan.

\section{Penentuan Atribut Kebutuhan Konsumen}

Atribut kebutuhan konsumen ditentukan dengan observasi dan diskusi dengan bagian principle dan sales perusahaan. Tools yang digunakan adalah cause effect diagram, dengan tools ini ditentukan faktor-faktor yang mempengaruhi kepuasaan konsumen terhadap kualitas produk, kestabilan dan harga. Hasil diskusi dilaporkan pada Lampiran.

\section{Survei Pendahuluan}

Diagram Pareto digunakan untuk menganalisis data survei pendahuluan. Dengan diagram Pareto ditentukan produk yang akan dijadikan kompetitor, diambil persentase kumulatif yang $\geq 80 \%$ (terdekat dengan angka $80 \%$ ). 
Manajemen Pemasaran ISSN No. (PRINT) 2598-0823, (ONLINE) 2598-2893

Tabel Daftar Atribut Kebutuhan Konsumen

\begin{tabular}{|l|l|l|}
\hline \multicolumn{1}{|c|}{ Primer } & \multicolumn{1}{|c|}{ Sekunder } & \multicolumn{1}{c|}{ Tersier } \\
\hline Kualitas Produk & Karakteristik & Kemampuan menganalisa sampel \\
\hline & & Kestabilan hasil \\
\hline & & Warna monitor \\
\hline & & Berat \\
\hline & & Dimensi \\
\hline Kemasan & Penampilan & Bentuk \\
\hline & & Keamanan bahan kemasan \\
\hline & & Dimensi kemasan \\
\hline & & Desain kemasan \\
\hline & & Terdapat logo merk \\
\hline Harga & & $\begin{array}{l}\text { Terdapat informasi } \\
\text { aksesories }\end{array}$ \\
\hline
\end{tabular}

Tabel Merk pH Meter yang Paling Sering Digunakan

\begin{tabular}{|l|c|c|c|}
\hline Merk pH Meter & $\begin{array}{c}\text { Jumlah Responden } \\
\text { yang menggunakan }\end{array}$ & Persentase & $\begin{array}{c}\text { Persentase } \\
\text { Kumulatif }\end{array}$ \\
\hline Metler & 40 & $57,14 \%$ & $57,14 \%$ \\
\hline Hanna & 8 & $11,43 \%$ & $82,86 \%$ \\
\hline Toa dkk & 10 & $14,29 \%$ & $71,43 \%$ \\
\hline Hach & 8 & $11,43 \%$ & $94,29 \%$ \\
\hline Togawa & 2 & $2,86 \%$ & $97,14 \%$ \\
\hline Chuo & 1 & $1,43 \%$ & $98,57 \%$ \\
\hline Lakmus & 1 & $1,43 \%$ & $100 \%$ \\
\hline JUMLAH & 70 & $100 \%$ & \\
\hline
\end{tabular}


Berdasar hasil analisa dengan diagram Pareto yang terdapat pada Lampiran 1 maka merk Metler, Hanna dan Toa dkk merupakan merk yang akan dijadikan sebagai produk kompetitor.

\section{Survei Konsumen}

\section{Pembuatan Kuesioner}

Kuesioner yang dibagikan kepada responden bertujuan untuk mendapatkan data tingkat kepentingan konsumen terhadap produk $\mathrm{pH}$ meter, data tingkat kepuasan konsumen terhadap produk pH meter Horiba, data tingkat kepuasan konsumen terhadap produk Metler, data tingkat kepuasan konsumen terhadap produk Hanna, data tingkat kepuasan konsumen terhadap produk Toa dkk serta data tingkat kepuasan yang diharapkan oleh konsumen yang digunakan sebagai data target. Kuesioner yang disebarkan ditampilkan pada Lampiran 2.

\section{Penyebaran Kuesioner}

Bersama dengan penyebaran kuesioner, diperlihatkan juga demo unit untuk $\mathrm{pH}$ meter Horiba. Responden diminta kesediaannya untuk melihat bentuk dan cara kerja $\mathrm{pH}$ meter Horiba, sebelum mengisi kuesioner untuk mengetahui tingkat kepuasan terhadap Horiba.

\section{Rekapitulasi Hasil Survei Konsumen}

Data hasil survei konsumen menunjukkan bahwa tingkat kepentingan responden bervariatif berada pada rentang sangat tidak penting sampai dengan sangat penting, begitu juga dengan tingkat kepuasan bervariasi dari puas sekali sampai tidak puas. Hasil selengkapnya ditampilkan pada Lampiran 4 dan dapat dilihat bahwa semua data terdistribusi normal.

\section{G. Kesimpulan}

Dari hasil analisis dan pembahasan yang dilakukan di PT. Pratama Graha Semesta telah diuraikan pada bab sebelumnya maka dapat ditarik kesimpulan, sebagai berikut:

1. Jenis produk $\mathrm{pH}$ meter yang banyak digunakan oleh konsumen adalah $\mathrm{pH}$ meter merk Mettler dengan jumlah persentase 57,14\%. Setelah melihat 
dari hasil Analisa PT. Pratama Graha Semesta sebaiknya menjual produk $\mathrm{pH}$ meter dengan melihat aspek dari keinginan dan kepuasan konsumen. Dan juga menambah informasi standar aksesories, ini merupakan salah satu cara peningkatan penjualan.

2. Terdapat 14 atribut yang berpengaruh terhadap kepuasan konsumen yaitu kemampuan menganalisa sampel, kestabilan hasil, warna monitor, berat produk, dimensi produk, bentuk produk, keamanan bahan pembuat, bentuk kemasan, dimensi kemasan, desain kemasan, ada logo, ada informasi standar aksesories, ada ijin Deperindag dan harga jual.

3. Keunggulan yang dimiliki oleh produk $\mathrm{pH}$ meter pesaing yaitu kemampuan analisa sampel lebih akurat, kestabilan hasil pembacaannya pasti, monitornya (layar) berwarna, dimensi kecil, sudah ada izin Deperindag, dan yang paling utama adalah produk berkualitas bagus dengan harga miring. Yang berarti bahwa semakin unggul produk yang disediakan dan semakin bagus penawaran harga (semakin bersaing) maka semakin tinggi tingkat keputusan pembelian, sehingga juga meningkatkan penjulan.

\section{H. Daftar Pustaka}

Cohen, L., 1995, Quality Function Deployment: "How to Make QFD Work for You", Addison-Wesley Publishing Company, Massachusetts.

Crow, Kerneth A., 2002, Customer-Focused Development with QFD, www.npdsolutions.com, online 2 Februari 2005.

Crow, Kerneth A., 2002, Performing QFD Step by Step, www.npd-solutions.com, online 2 Februari 2005.

Day, R.G., 1993, Quality Function Deployment: Linking a Company with Its Customers, ASQC Quality Press, Wisconsin.

GasperzVincent.,1997, “Manajemen Bisnis Total”, Gramedia, Jakarta.

GasperzVincent., 2002, "Pedoman Implementasi Program Six Sigma Terintegrasi dengan ISO 9001:2000, MBNQA, dan HACCP", Gramedia, Jakarta

Goetsch, D.L. and Davis, S.B., 1997, “Introduction to Total Quality Management for Production, Processing, and Services", $2^{\text {nd }}$ ed., Prentice-Hall International, New Jersey. 
Lowe, A.J. and Ridgway, K., 2001, Quality Function Deployment, www.teamset.com.

Mc Daniel, Carl dan Gates, Dodger, 2001, Riset Pemasaran Kontemporer, buku 1, Salemba Empat, Jakarta.

Shilito, M.L., 1994, “Advanced Quality Function Deployment: Linking Technology to market and Company Needs", John Willey and Sons Inc, UK.

Simon, K., 2005, Pareto Chart, www.iSixSigma.com, on line 13 Februari 2005.

Sugiyono, 2004, Metode Penelitian Bisnis, Cetakan Ketujuh, Alfabeta, Bandung.

Timperley, S., 2003, Howto_Pareto, www.btf_processimprovement.com, online 11 Februari 2005.

Tjiptono, F. dan Diana, A., 2002, Total Quality Management, edisi keempat cetakan 2, Andy, Yogyakarta.

Tjiptono, Fandy.2002. Strategi Pemasaran, edisi 2. cetakan 6, Andy, Yogyakart. 